\title{
Behind the Façade of Fee-Free Education: Shadow Education and its Implications for Social Justice
}

\author{
Mark Bray \& Ora Kwo \\ The University of Hong Kong
}

\begin{abstract}
:
Most governments, at an official level, espouse the principles of the 1948 Universal Declaration of Human Rights. Among its statements is that education shall be free, at least in the elementary and fundamental stages. Yet while the façade of government education systems presents an image that instruction is free of charge, families across the world increasingly find it necessary to invest in the socalled shadow education system of private supplementary tutoring. The spread of shadow education, which is no longer confined to relatively prosperous families, has far-reaching implications for social inequalities and therefore social justice. It is a hidden form of privatisation behind the façade of public education systems; and the fact that shadow education is seen by many families as unavoidable appears to be incompatible with the spirit of the Universal Declaration. The question then is whether the spirit of the Universal Declaration should be abandoned, or whether it should be protected - and, if so, how.
\end{abstract}

Keywords: privatisation; shadow education; private tutoring; fees; social justice

\section{Introduction}

Among the best known proclamations on social justice is the 1948 Universal Declaration of Human Rights. This document underpins the work of the United Nations and its collaborators, and is a core component of the Education for All (EFA) movement of which the United Nations Educational, Scientific and Cultural Organization (UNESCO) is the lead agency.

The Universal Declaration stated not only that everyone has the right to education but also that education shall be free of charge. Much advocacy and some national constitutions continue to espouse these principles. Yet behind the façade of fee-free public provision of education are increasing volumes of private supplementary tutoring. Such tutoring has become widely known as shadow education because as the curriculum in the school system changes, so the curriculum changes in the shadow; and as the mainstream gets larger, so does the shadow. The spread of shadow education has become a hidden form of privatisation in many education systems. In some societies, payment for shadow education has in effect become obligatory even for low-income families because 
of the demands of the school system and society. Thus, investment in the private form of education alongside fee-free receipt of public education has become a common pattern.

This paper begins with a sketch of relevant international resolutions and of the EFA agenda. It then turns to the scale and nature of shadow education around the world, highlighting its existence in both high-income and low-income countries. The paper then identifies ways in which shadow education can undermine the EFA objectives of quality education for all. This leads to consideration of the extent to which the relevant clause of the Universal Declaration of Human Rights still has pertinence in contemporary times, and of the implications for government policy.

\section{United Nations Declarations and Their Counterparts}

The era up to 1989

Much has been written about the Universal Declaration of Human Rights and the turbulent period of history from which it emerged (e.g. Lauren 1998; Glendon 2001; Levin 2009; Mertus 2009). For present purposes, the principal relevant clause is Article 26.1. It states (United Nations 1948) that:

Everyone has the right to education. Education shall be free, at least in the elementary and fundamental stages. Elementary education shall be compulsory. Technical and professional education shall be made generally available and higher education shall be equally accessible to all on the basis of merit.

Like many clauses in the Declaration, this one resulted not only from debate but also some compromise. Tomasevski (2003: 42) noted the "huge controversy" during the drafting process around the notion that education should be both a right and a duty. The Lebanese and Indian delegations argued that it was contradictory to make education a right and then to add compulsion, and the United

Kingdom opposed the wording "because it could be interpreted as acceptance of the concept of State education” (Tomasevski 2003: 42). In the voting, the word 'compulsory' was saved by a majority of just one.

The dimension of free provision then followed because delegates argued that elementary education could only be compulsory if it was free. In this decision-making on explicit compulsion and free provision, education was treated differently from other rights. For example, Article 25 included the right to clothing, which social norms also dictated to be compulsory. However, no suggestion was made that clothing should also be free. Similarly, Article 25 declared health care to be a human right, but it made health care neither free nor compulsory. Advocates perceived a social risk from failing to make education compulsory. The French delegate, for example, asserted that the "compulsory nature [of primary education should] ... be explicitly stated, so that parents would not be able to neglect their duty to their children” (Morsink 1999: 213). Arguments could have been made that basic medical provision was essential for limiting the spread of diseases, and the Soviet delegation did propose inclusion of housing and medical care "at the expense of the State or of employers" (Morsink 1999: 
202). However, this proposal was not retained in the final version, and in the financial domain education was thus treated differently from other rights.

During the decades that followed, the sentiments on education in the Universal Declaration were echoed in other documents. Thus, the Declaration of the Rights of the Child (United Nations 1959, Principle 7) stated that:

The child is entitled to receive education, which shall be free and compulsory, at least in the elementary stages.

And the International Covenant on Economic, Social and Cultural Rights (United Nations 1966, Article 13) declared that:

(a) Primary education shall be compulsory and available free to all.

(b) Secondary education in its different forms ... shall be made generally available and accessible to all by every appropriate means, and in particular by the progressive introduction of free education.

(c) Higher education shall be made equally accessible to all, on the basis of capacity, by every appropriate means, and in particular by the progressive introduction of free education.

Since that era, dominant views on the financing of higher education have changed. This partly reflects the general expansion of higher education, and thus of the burden on governments. It also reflects awareness that even with fee-free provision, students from middle-income and rich families are much more likely to receive higher education (and thus to receive subsidies) than students from poor families. The current dominant international view, therefore, is that public higher education institutions should charge at least some fees, while the needs of students in low-income families should be protected by provision of scholarships, grants and perhaps loans (Greenaway \& Haynes 2004; Johnstone \& Marcucci 2010).

Concerning lower levels of education, the Convention on the Rights of the Child was in line with predecessors in asserting (United Nations 1989, Article 28) that states should:

(a) Make primary education compulsory and available free to all;

(b) Encourage the development of different forms of secondary education, including general and vocational education, make them available and accessible to every child, and take appropriate measures such as the introduction of free education and offering financial assistance in case of need.

The third clause was that states should:

(c) Make higher education accessible to all on the basis of capacity by every appropriate means. 
Although the first two clauses were an explicit echo of the 1966 International Covenant, the third clause had already dropped the notion of making higher education free.

\section{The EFA Movement}

The EFA movement was launched in 1990 in Jomtien, Thailand, at the World Conference on Education for All (WCEFA). The event was convened by UNESCO, the United Nations Children's Fund (UNICEF), the United Nations Development Programme (UNDP), and the World Bank. It brought together delegations from 155 countries, 33 intergovernmental organizations, and 125 nongovernmental organizations and institutes (WCEFA 1990a).

The Declaration that emerged from the Conference (WCEFA 1990b) commenced with the 1948 Universal Declaration of Human Rights, and asserted a renewed commitment to the right to education. Article 1 stressed that "Every person - child, youth and adult - shall be able to benefit from educational opportunities designed to meet their basic learning needs”; and Article 2 identified an "expanded vision" that surpassed existing resource levels, institutional structures, curricula, and conventional delivery systems. Article 4 emphasised that whether or not educational opportunities would translate into meaningful development "depends ultimately on whether people actually learn as a result of those opportunities, i.e., whether they incorporate useful knowledge, reasoning ability, skills, and values”. Nevertheless, the most prominent goal to emerge from the Conference was of quantitative enrolments in the form of universal primary education and a target date of 2000.

The Conference recognised that education had to be paid for somehow, and did not assert that schooling should be free of charge. Instead, the Final Report (WCEFA 1990a: 31) included open discussion of fees; and Article 7 of the Declaration (WCEFA 1990b) stressed the importance of partnerships:

National, regional and local educational authorities have a unique obligation to provide basic education for all, but they cannot be expected to supply every human, financial or organizational requirement for this task. New and revitalized partnerships at all levels will be necessary ... [including] partnerships between government and non-governmental organizations, the private sector, local communities, religious groups, and families.

The report of the thematic roundtable on financing (Windham 1992: 80) noted that:

A number of advocates of education policy reform, including some aid agencies and international financial institutions, have in recent years concluded that additional resources for education will have to come from private rather than public sources in the developing world.

The report recognised that public schools sometimes charged fees, "albeit seldom sufficient to fully cover costs” (p.81), and left the door open to continuation of that practice. 
Ten years later, a follow-up World Education Forum (WEF) was convened in Dakar, Senegal. The 1,100 participants included delegations from 164 countries. The stocktaking noted progress and shortfalls, and delegates renewed commitment to the EFA ideal. The documentation returned to the pre-1990 refrain that primary education should be free of charge (WEF 2000: 15):

For the millions of children who live in poverty, who suffer multiple disadvantages, there must be an unequivocal commitment that education be free of tuition and other fees, and that everything possible be done to reduce or eliminate costs such as those for learning materials, uniforms, school meals and transport. Wider social policies, interventions and incentives should be used to mitigate indirect opportunity costs of attending school.

The EFA agenda was subsequently linked to the United Nations' eight Millennium Development Goals (MDGs), prepared during the same period. The second of the MDGs was to "ensure that, by 2015, children everywhere, boys and girls alike, will be able to complete a full course of primary schooling” (United Nations 2000). However, the EFA agenda was broader than just universal primary education. It included expanding and improving early-childhood care and education; ensuring that the learning needs of all young people and adults are met through equitable access to appropriate learning and life-skills programmes; improving adult literacy rates; eliminating gender disparities in primary and secondary education; and improving all aspects of the quality of education. Much progress was achieved during the years that followed, but by 2007 it was already clear that a significant shortfall would be inevitable at the time of the 2015 target date (UNESCO 2007; see also Lewin 2011).

\section{The Expansion and Increasing Significance of Private Supplementary Tutoring}

Private supplementary tutoring is not a new phenomenon. In earlier centuries private tutoring was a precursor and alternative to schooling for some social classes in some societies; and even when those classes subsequently sent their children to school instead of to private tutoring, some families still employed tutors to provide extra educational help for their children. However, the current scale of tutoring is much greater than in previous periods of history. During the last quarter of the $20^{\text {th }}$ century shadow education emerged as a major feature in parts of East Asia (Harnisch 1994; Bray 1999; Zeng 1999); and since that time the shadow has spread globally on a significant scale (Bray 2009; Lee et al. 2009; Mori \& Baker 2010). The expansion of shadow education, and its penetration to poor as well as middle-income and rich communities, has far-reaching implications.

To demonstrate this point, it is useful first to note the scale of shadow education in a spread of countries (Table 1). While shadow education is especially evident at the senior secondary level, in some countries it is also prominent at what the Universal Declaration of Human Rights called the elementary and fundamental stages. 


\begin{tabular}{ll}
\hline Country & Patterns \\
\hline Bangladesh & According to a government-conducted household survey, in 2008 68.4\% of secondary students and \\
& 37.9\% of primary students were receiving tutoring (Nath 2011: 3). \\
Canada & In 2007, about one third of Canadian parents reported that they had hired tutors for their children. \\
& The number of businesses providing tutoring services had expanded between 200\% and 500\% in \\
& major Canadian cities during the previous three decades (Davies \& Guppy 2010: $111-112$ ).
\end{tabular}

China $\quad$ A 2010 survey of 1,397 Grade 12 students in Jinan city found that 23.1\% were receiving supplementary tutoring in mathematics; and in a parallel sample of 1,101 students, $18.2 \%$ received tutoring in English (Zhang 2013: 8).

Egypt A 2009 report indicated that $81 \%$ of households with children in secondary schools had paid for tutoring. At the primary level, 50\% had done so (Sobhy 2012: 49).

England A 2008 survey of 1,500 parents random telephone calling indicated that 12\% of primary school children and 8\% of secondary school students were receiving tutoring (Peters et al. 2009: 2).

Georgia A 2010 survey of 1,200 students found that 15\% in primary grades and 57\% in the final secondary grade received private tutoring (Machabeli et al. 2011: 14).

Germany A 2010 report indicated that 1.1 million pupils, representing $14.8 \%$ of the student population, received regular tutoring (Klemm \& Klemm 2010: 7).

Ghana A 2008 survey of 1,020 households found that $48 \%$ were paying for private tutoring in primary education (Antonowicz et al. 2010: 21)

India A 2011 survey indicated that $61.0 \%$ of Grade 1 students in rural government schools in Tripura State received private tutoring, and the proportion rose to $75.0 \%$ in Grade 6. In West Bengal, respective proportions were 55.6\% and 77.5\% (Pratham 2012: 215, 235).

Pakistan A 2011 survey showed that tutoring was especially prominent in cities. In Lahore, 60.5\% of students in Grades 1-10 received tutoring, and in Karachi the figure was 47.8\% (SAFED 2012: 395). Proportions increased at higher grades but were prominent even in Grade 1. In Karachi, 35.5\% of Grade 1 children in government schools received tutoring; and in Lahore the proportion was $35.7 \%$.

Romania A survey of 1,500 children aged 6-19 in 2010 found that 17\% were receiving tutoring (Daedalus Millward Brown 2010).

South In 2008, 60.5\% of pupils in general high school were estimated to be receiving tutoring. In middle

Korea $\quad$ school the proportion was 72.5\%; and in primary school it was 87.9\% (Kim 2010: 302).

Tunisia A 2008 survey of 250 households (quoted by Akkari 2010: 51) found that 73.2\% paid for tutoring among whom $90.2 \%$ described it as a strain on the family budget. The phenomenon existed from the first year of elementary school.

Vietnam A 2006 survey of 9,189 households found that 32.0\% of primary children were receiving tutoring. In lower and upper secondary schooling, respective proportions were $46.0 \%$ and $63.0 \%$ (Dang 2011).

It is commonly assumed that most private tutoring is received by pupils who are lagging behind their peers and wish to keep up. This group is significant, but tutoring is more common among students who are already performing well and wish to maintain their competitive edge. The principal subjects are those which are crucial to progress in the education system. This typically means mathematics and languages, and may include sciences or humanities depending on the streams chosen by the students. Some students receive tutoring throughout the year, while others mainly receive it immediately before major examinations. 
Comparative survey also shows diversity in the types of tutoring. At one end of the spectrum is one-to-one tutoring received by students at home or elsewhere. At the other end are classes in lecture theatres with overflow rooms served by video screens, as exemplified by the operations of 'star tutors' in Hong Kong (Kwo \& Bray 2011). In between is tutoring in small groups or in mediumsized classes. In addition, technology is permitting tutoring through the internet within and across national boundaries (Ventura \& Jang 2010).

Further variations arise in the identities of tutors. Some tutoring is provided by university students and even secondary students as a way to earn extra pocket money. Other tutoring is provided by self-employed people working full-time or part-time; and recent decades have brought considerable expansion of tutoring through companies, some of which operate national or international franchises (Davies \& Aurini 2006; Burch 2009).

In some countries, many full-time teachers also provide private supplementary tutoring. This can benefit the wider society and the students, being a mechanism through which extra use of the teachers' talents is secured and through which students gain further attention from teachers who already know them well. However, it can also raise concerns about corruption, particularly when teachers provide tutoring to students for whom those teachers are already responsible in regular classes. Dawson (2009) has highlighted the "tricks of the teacher" in Cambodia, noting that some teachers deliberately reduce their effort during regular classes in order to promote demand for the extra lessons. Similar problems have been noted elsewhere in Asia and in parts of Africa, Europe and the Middle East (Foondun 2002; Akkari 2010; Gök 2010; Farah 2011; Johnson 2011; Sobhy 2012).

\section{Implications for the EFA Agenda}

The core of the EFA agenda is about human rights and social justice, both of which are allied to issues of inequalities. In line with this thrust, the following section commences with inequalities. It then turns to the impact of quantitative expansion on the quality of education. Thirdly, the section notes ways in which shadow education can be subtractive as well as supplementary to mainstream schooling.

\section{Shadow education and social inequalities}

Shadow education, if left to market forces, is likely to perpetuate and increase social inequalities since higher-income households are able more easily than lower-income households to afford both superior quality and greater amounts of private tutoring. This pattern also of course applies in regular schooling: rich families can send their children to types of private schools that are out of reach for poor families. However, as shadow education has expanded, middle-income and low-income families have found themselves forced to invest in private tutoring alongside public provision that is supposedly egalitarian. 
An example from India illustrates this point. The Pratichi Trust surveyed education in West Bengal in 2001/02 and again in 2008/09. The first report showed many shortcomings, some of which had been alleviated by the time of the second report. However, the second report observed increased dependence on private tutoring for pupils in both primary schools and Sishu Siksha Kendras (SSKs), which are community-based alternatives to primary schools. Sen (2009: 13) observed that:

The proportion of children relying on private tuition has gone up quite a bit (64\% from 57\% for the students of standard primary schools, and 58\% from $24 \%$ for SSK children). Underlying this rise is not only some increase in incomes and the affordability of having private tuition, but also an intensification of the general conviction among the parents that private tuition is "unavoidable" if it can be at all afforded (78\% of the parents now believe it is indeed "unavoidable" - up from 62\%). For those who do not have arrangements for private tuition, $54 \%$ indicate that they do not go for it mainly - or only - because they cannot afford the costs.

Comparable observations have been made in Africa. In Madagascar, for example, Andriamahavonjy and Ravelo (2009: 38) described tutoring as "almost obligatory for all students". And in Egypt, Sobhy (2012: 47) observed that:

Almost from a child's first year in school, poor families ... are pressured and intimidated by poorly paid teachers to enrol their children in private tutoring in order to pass from one year to the next. Middle and upper middle class families are equally pressured to enrol their children in tutoring to secure an acceptable level of education.

Sobhy added (p.48) that:

The concrete ways in which 'informal' tutoring markets have been established within and alongside formal schooling have transformed state institutions and informed a sense of injustice perceived in their operation. Tutoring on this scale has profound implications for equity, access to education, and the content and quality of youth schooling experiences.

Tutoring consumed one fifth of the incomes of poor households, in a country where schooling was supposedly free.

Data from these and other countries show, as one would expect, that absolute expenditures on shadow education are lower in low-income households than in middle-income and high-income households. However, the data also show that many low-income households perceive a necessity to invest in shadow education despite the constraints on their budgets. For example, 2008 data in South Korea indicated that while $91.8 \%$ of households in the highest of eight income groups invested in tutoring, the figure was still as much as $34.3 \%$ in the lowest income group and $55.3 \%$ in the next lowest (Kim 2010: 303-304). Similar patterns emerged from Smyth’s (2009: 9) data in Ireland. While $58 \%$ of students from higher professional households had received private tutoring, the proportions 
were still as high as 32\% among students from semi-skilled households and $28 \%$ from unskilled households. Again, among the Georgian students surveyed by Machabeli et al. (2011: 16), 90\% considered private tutoring a necessity, and $60 \%$ of the respondents who did not receive tutoring stated lack of funds as the only reason.

\section{Quantitative expansion and qualitative decline}

As noted above, the EFA agenda has placed strong emphasis on quantitative enrolments. In many settings, the expansion is perceived as having been achieved at the expense of quality. Schools have introduced double or even triple shifts; untrained teachers and poorly trained teachers have been recruited; and facilities have been stretched even more thinly than before (UNESCO 2004; Acedo et al. 2012). These patterns have been especially obvious in the less developed countries of Africa and Asia. For example, data from the Southern and Eastern Africa Consortium for Monitoring Educational Quality (SACMEQ) have shown sharp declines in achievement scores in Mozambique due to "massive increases in Grade 6 enrolments without corresponding increases in human and material resources" (Makuwa 2010: 3). Six other countries in the region showed mixed performance, which highlighted "the EFA challenge for all countries to strike a balance between increases in enrolment and improvements in quality of education for all” (Makuwa 2010: 3).

The scale of private tutoring is not always correlated with quality, at least in an absolute sense. Some countries with strong education systems, such as Japan, South Korea and Singapore, have extensive tutoring; and some countries with weak education systems, such as the Democratic Republic of Congo and Papua New Guinea, have relatively little tutoring. In these cases, the scale of tutoring reflects the nature of social competition rather than absolute levels of educational quality.

Nevertheless, expansion of school systems in order to achieve the EFA enrolment goals has led families in some countries to consider the quality of education provided by public schools as inadequate to meet their needs and aspirations. Some families have migrated to the private sector (see e.g. Oketch et al. 2010; Noronha \& Srivastava 2012), while others have remained in the public sector but supplemented the diet with additional tutoring. In Cambodia, for example, the double-shift school day lasts only four hours, and even diligent teachers assert that it is impossible to cover the full curriculum (Dawson 2010: 20). Similar constraints are evident in Vietnam, where the authorities implicitly recognise the problem by prohibiting teachers from offering private tutoring to pupils in full-day schools but by permitting them to offer it to pupils in double-shift schools. Researchers have indicated that children with lower self-reported school quality are more likely to receive extra classes (Ko \& Xing 2009: 33).

\section{Subtraction as well as addition}

Several remarks have alluded to ways in which shadow education may negatively affect regular schooling. Teachers who are also tutors may reduce their efforts in regular classes. This danger is 
especially great if the teachers gain payment by tutoring their existing students; but even if they tutor other students, they may reserve their energies for classes in which students are clients rather than for regular classes for which a standardised income is guaranteed and students cannot easily leave if they are dissatisfied. Aslam and Mansoor (2012: 3) have commented on the problems in Pakistan where government teachers are "virtually un-sackable" and the culture of extra tutoring has become entrenched (see also Aslam \& Atherton 2012: 25). And in Turkey, Gök (2010: 132) highlighted the case of a teacher who told a student: “You didn't attend my private course so I'm not talking to you anymore”. Again with reference to West Bengal, India, Sen (2009: 14-15) observed not only that the tutoring classes covered content that could and should have been taught in the regular lessons, but also that tutoring made improvements more difficult since the more influential families had less stake in the quality of what was done in the schools, feeling that they could pay for the supplementation outside school hours.

The shadow sector also contributes to neglect of certain geographic areas, subjects and levels of education. In Egypt, Sobhy (2012: 56) noted the difficulties in recruiting teachers of art, music and sports and of attracting teachers to rural areas "where tutoring is not profitable enough". Similar remarks would apply to low-income communities in urban areas; and teachers commonly prefer to work in higher grades where examination pressures become more evident, thereby neglecting the foundations of education systems.

In addition, shadow education may damage the regular schools by taking away talent altogether. Where teachers are not permitted also to be tutors, some teachers may choose to leave the school sector and others never join. The tutoring industry has many amateurs, but it also has many strong professionals. In some countries the tutoring sector is perceived to be innovative in use of technology and pedagogical approaches. When the market attracts talented tutors and administrators to the shadow sector, it leaves the regular system more impoverished than it otherwise would be.

Viewing patterns in a different way, when the shadow sector and the schools operate in a complementary way they can achieve efficient modes. Many testimonies can be cited in which tutoring has helped to overcome learning obstacles and has reinforced content which was touched upon in regular classes but not fully comprehended (e.g. Marhic 2009: 67-73; Walls 2009: 209-216). Yet a corollary can be that children are exhausted from excessive regimes of full-time schooling plus academic tutoring, and have inadequate time for sports, hobbies and relaxation. This has a psychological toll, and can lead to inefficient use of school time. In South Korea, Kim (2007: 7-8) noted that many of the young people who attend tutorial centres until late in the evening have inadequate energy for daytime schooling. Since they are paying for the tutorial classes, the students value them more; and since they are nevertheless required to go to school, they sleep during many daytime lessons. 


\section{Revisiting the Universal Declaration of Human Rights}

Although the processes of drafting Article 26 of the Universal Declaration exposed disagreement, particularly on compulsion and therefore making education free, at least on the surface the voting procedures resolved the disagreement. As early as 1951 UNESCO reported that "the principle of universal compulsory education is no longer questioned" (Tomasevski 2003: 44), and the notions both of compulsion and free education entered the general discourse of development and good governance. The principles were enshrined in the constitutions of some countries gaining independence in subsequent decades (Tomasevski 2003: 69); and they received more contemporary prominence in the legislation of some other countries (e.g. India 2009; Pakistan 2010).

The question then is why at the beginning of the $21^{\text {st }}$ century education is still not truly compulsory in many countries, and why, even in settings where it is compulsory, it is not free. Part of the answer lies in the costs. Schooling is a heavy financial burden for governments, which commonly allocate $15-20 \%$ of their budgets to education and in some cases devote $25 \%$ or more (UNESCO 2007: 142; UNESCO Institute for Statistics 2011: 29). Privatisation, as many commentators have observed (e.g. Belfield \& Levin 2002: 30; Kitaev 2007: 93), is one way to spread the load. Most obviously, privatisation occurs when increasing proportions of children attend private rather than public schools; but it can also occur through increased private contributions to public systems. Specifically in the case of shadow education, the prevalence of private supplementary tutoring allows the state to provide just the minimum in the regular system since families will pay for 'extras'. Sobhy (2012: 47) states that this has been a deliberate strategy by the Egyptian government, and no doubt other governments have also seen shadow education from this perspective.

Such factors may be linked to teachers' salaries, which at the elementary level are always the largest component of government expenditures. Teachers around the world complain that they are not paid adequately, and in many settings their complaints are justified. One way to pacify the teachers, and also to retain them in the profession, is to allow them to supplement their incomes through tutoring.

Patterns may also be linked to the rise of the neoliberal approach to education, in which it has become acceptable for education to be treated as a marketable service (Belfield \& Levin 2002; Zajda 2006; Ball \& Youdell 2008). This was not the dominant notion among United Nations delegates in 1948. The debates were mainly between the Western powers on the one hand and the Soviet Union and its allies on the other hand. On the theme of compulsory education, they converged from very different angles. Much of the drafting was led by delegates from the USA and France, in which stateprovided education had a long tradition; and delegates were sympathetic to a view expressed by the Philippines representative who placed at the forefront the recent memories of the Second World War, stressing that "the events of recent years ha[d] shown that an enlightened and well-informed public constituted the best defense of democracy and progress” (Morsink 1999: 202). The Soviet bloc had a 
very different overall emphasis, but also strongly supported provision of education by (and for) the state within the communist framework.

Subsequent decades brought radical changes. The Soviet Union collapsed in 1991, and accompanying economic crisis brought severe difficulties for many professionals. During the 1990s, teachers in former Soviet countries who remained in government schools could not easily provide for their families on official salaries, and it became acceptable for them to supplement their incomes through tutoring. Once this tradition became installed, it remained part of the new architecture even when economies strengthened (Silova et al. 2006; Silova 2010; Borodchuk 2011). Western countries have been subject to different forces, but also in these countries marketisation of education became increasingly prominent, accelerated in some cases by fiscal austerity (Ball \& Youdell 2008; Burch 2009; Bray 2011).

In turn, these forces have led to window-dressing when governments espouse fee-free education in UNESCO forums and on other occasions, even though considerable payments are being made through the tutoring industry and other channels. Ministries of Education prefer not to know too much about the shadow education sector; and if confronted, they may say that shadow education is beyond their remit and that in any case parents have the right to pay for extra services if they wish.

The question then is whether indeed the ideology of the Universal Declaration should hold, or whether the Declaration should be viewed as a product of its times which no longer fits current circumstances. The answers to this question of course depend on the viewpoints of the respondents. A strong case can be made for universalisation of elementary education, in line with the EFA objectives and the Millennium Development Goals; but experiences during the decades since 1948 have shown that universalisation is much more than just a question of supply of school places. Adequate quality and perceived relevance of education are also essential to attract and retain children in school. Quality and relevance demand considerable resources, and the issue is therefore to some extent a matter of priorities within government budgets.

Further, if some parents choose to invest in supplementary tutoring, is it reasonable for the state to forbid them? The Soviet answer was that private tutoring should be forbidden, even though tutoring did still occur beyond the official gaze (see e.g. Hrynevych et al. 2006: 305; UNDP 2007: 64). In the post-Soviet era, private enterprise in general has been actively encouraged and in most countries the shadow education sector is at least tolerated. Similar remarks apply to China, which operates a "socialist market economy” (Crabb 2010; Zhang 2013). In neighbouring South Korea, the government did ban tutoring in 1980 but was challenged in the courts which eventually determined in 2000 that such prohibition was unconstitutional (Lee et al. 2010: 101). It does not seem likely that other governments would be more successful within their existing legal frameworks. In other words, it would seem a general principle that parents do indeed have the right to pay for supplementary services, even though the practice may create a backwash that burdens families who cannot easily afford it and may altogether exclude some families from basic educational provision. 


\section{Conclusion}

The assertions that, for reasons of social justice, at least elementary education should be universal, compulsory and free of charge have a strong ancestry in various United Nations proclamations, and particularly in the Universal Declaration of Human Rights. Few contemporary advocates recognise the possible dissonance between making an activity a right and also making it compulsory, and even fewer recognise that compulsion was retained in the Universal Declaration by a margin of just one vote.

Much of the concern about privatisation of education systems and the impact of neo-liberal ideologies has focused on the existence and operation of schools that are operated privately and attract children as an alternative to public institutions. Less focus has been devoted to shadow education which in many settings is a fee-paying supplement received by children in officially fee-free systems. When operating positively, supplementary tutoring can help students to overcome obstacles to learning and can stretch further the achievements of talented pupils. It can synergise well with regular lessons, and may contribute to both economic and social development. However, shadow education can also undermine mainstream schooling, leading to inefficiencies and to exclusion of some social groups. Sen (2009: 14-15) remarked in the context of West Bengal, India, that tutoring "divides the student population into haves and have-nots", and "effectively negates the basic right of all children to receive elementary education”. These remarks would be echoed in other contexts.

Shadow education was not considered either during the 1990 World Conference on Education for All or during the 2000 World Education Forum. The chief reason was that the events focused on schooling as provided by Ministries of Education and similar bodies. Shadow education was certainly a major problem in some countries (see e.g. Joynathsing et al. 1988; Marimuthu et al. 1991; de Silva 1994), but the research evidence was limited. By the beginning of the second decade of the $21^{\text {st }}$ century, shadow education had become a significant phenomenon in almost all parts of the world, and the research evidence was stronger. Much further attention is needed to the scale, nature and impact of shadow education. A strong case can be made for bringing it into the mainstream of discourse about EFA and the role of education in promoting and/or inhibiting social justice.

\section{References}

Acedo, C., Adams, D. \& Popa, S. (Eds) (2012) Quality and qualities: Tensions in education reforms (Rotterdam: Sense).

Akkari, A. (2010) Privatizing education in the Maghreb: A path for a two-tiered education system, in: A.E. Mazawi \& R.G. Sultana (Eds) Education and the Arab 'world': Political projects, struggles, and geometries of power (London, Routledge), 43-58.

Andriamahavonjy, F. \& Ravelo, A. (2009) Enquête nationale d'évaluation du secteur éducation primaire publique à Madagascar (Antananarivo, Transparency International). 
Antonowicz, L., Lesné, F., Stassen, S. \& Wood, J. (2010) Africa education watch: Good governance lessons for primary education (Berlin, Transparency International).

Aslam, M. \& Mansoor, S. (2012) The private tuition industry in Pakistan: An alarming trend. Policy Brief (Islamabad: South Asia Forum for Education Development).

Aslam, M. \& Atherton, P. (2012) The 'shadow' education sector in India and Pakistan: The determinants, benefits and equity effects of private tutoring. ESP Working Paper 38 (Budapest: Education Support Program, Open Society Foundations).

Ball, S.J. \& Youdell, D. (2008) Hidden privatisation in public education (Brussels, Education International).

Belfield, C.R. \& Levin, H.M. (2002) Education privatization: Causes, consequences and planning implications (Paris: UNESCO International Institute for Educational Planning).

Borodchuk, N. (2011) Shadow education: Quantitative and qualitative analysis of the impact of the educational reform (implementation of centralized standardised testing) on private tutoring in Ukraine. Working papers series 11-117 (Development Studies Institute, London School of Economics and Political Science).

Bray, M. (1999) The shadow education system: Private tutoring and its implications for planners (Paris, UNESCO International Institute for Educational Planning).

Bray, M. (2009) Confronting the shadow education system: What government policies for what private tutoring? (Paris, UNESCO International Institute for Educational Planning).

Bray, M. (2011) The challenge of shadow education: Private tutoring and its implications for policy makers in the European Union (Brussels, European Commission).

Burch, P. (2009) Hidden markets: The new education privatization (New York, Routledge).

Crabb, M.W. (2010) Governing the middle-class family in urban China: Educational reform and questions of choice. Economy and Society, 39 (3), 385-402.

Daedalus Millward Brown (2010) Piata Meditatiilor, estimate la peste 300 milione euro anual. Study commissioned by Fundatia Dinu Patriciu, Bucharest. www.fundatiadinupatriciu.ro/ro/media_room/stiri/249, accessed 10 January 2013.

Dang, H.A. (2011) Private tutoring in Vietnam: A review of current issues and its major correlates. Unpublished manuscript (Washington DC, The World Bank).

Davies, S. \& Aurini, J. (2006) The franchising of private tutoring: a view from Canada, Phi Delta Kappan, 88 (2), 123-128.

Davies, S. \& Guppy, N. (2010) The schooled society: An introduction to the sociology of education. Toronto: Oxford University Press.

Dawson, W. (2009) The tricks of the teacher: Shadow education and corruption in Cambodia, in: S.P. Heyneman (Ed), Buying your way into heaven: Education and corruption in international perspective (Rotterdam, Sense Publishers), 51-74.

Dawson, W. (2010) Private tutoring and mass schooling in East Asia: Reflections of inequality in Japan, South Korea, and Cambodia. Asia Pacific Education Review, 11 (1), 14-24.

de Silva, W.A. (1994) Extra-school tutoring in the Asian context with special reference to Sri Lanka. (Mahargama, National Institute of Education).

Farah, S. (2011) Private tutoring trends in the UAE. Policy Brief No.26 (Dubai, Dubai School of Government).

Glendon, M.A. (2001) A world made new: Eleanor Roosevelt and the Universal Declaration of Human Rights (New York, Random House). 
Foondun, A.R. (2002) The issue of private tuition: An analysis of the practice in Mauritius and selected south-east Asian countries. International Review of Education, 48 (6), 485-515.

Gök, F. (2010) Marketing hope: Private institutions preparing students for the university entrance examination in Turkey, in: K. Amos (Ed), International educational governance. (London, Emerald), 123-134.

Greenaway, D. \& Haynes, M. (2004) Financing education, in: G. Johnes \& J. Johnes (Eds) International handbook on the economics of education (Cheltenham, Edward Elgar), 298-328.

Harnisch, D.L. (1994) Supplemental education in Japan: Juku schooling and its implication, Journal of Curriculum Studies, 26 (3), 323-334.

Hrynevych, L., Toropova, A., Pylnyk, T., Sereda, L. \& Gerasevich, U. (2006) Ukraine, in: Silova, I., Būdienè, V. \& Bray, M. (Eds), Education in a hidden marketplace: Monitoring of private tutoring (New York, Open Society Institute), 305-325.

India, Ministry of Law \& Justice (2009) The right of children to free and compulsory education act, 2009 (New Delhi, Government of India Press).

Johnson, E.M. (2011) Blaming the context not the culprit: Limitations on student control of teacher corruption in post-Soviet Kyrgyzstan, in: I. Silova (Ed), Globalization on the margins: Education and postsocialist transformations in Central Asia (Charlotte, Information Age), 233258.

Johnstone, D.B. \& Marcucci, P.N. (2010) Financing higher education worldwide: Who pays? Who should pay? (Baltimore, Johns Hopkins University Press).

Joynathsing, M., Mansoor, M., Nababsing, V., Pochun, M. \& Selwyn, P. (1988): The private costs of education in Mauritius (Réduit, School of Administration, University of Mauritius).

Kim, M. (2007) School choice and private supplementary education in South Korea. Paper IIEP/SEM 279/7. (Paris, UNESCO International Institute for Educational Planning).

Kim, K.K. (2010) Educational Equality, in: C.J. Lee, S.Y. Kim \& D. Adams (Eds), Sixty years of Korean education (Seoul, Seoul National University Press), 285-325.

Kitaev, I. (2007) Education for all and private education in developing and transitional countries, in: Srivastava, P. \& Walford, G. (Eds) Private schooling in less economically developed countries: Asian and African perspectives (Oxford, Symposium Books), 89-109.

Klemm, K. \& Klemm, A. (2010) Ausgaben für Nachhilfe: teurer und unfairer Ausgleich für fehlende individuelle Föderung (Gütersloh, Bertelsmann Stiftung).

Ko, I. \& Xing, J. (2009) Extra classes and subjective well-being: Empirical evidence from Vietnamese children. Young Lives Working Paper No.49 (Department of International Development, University of Oxford).

Kwo, O. \& Bray, M. (2011) Facing the shadow education system in Hong Kong, IIAS Newsletter (University of Leiden, International Institute for Asian Studies), 56, 20.

Lauren, P.G. (1998) The evolution of international human rights: Visions seen (Philadelphia, University of Pennsylvania Press).

Lee, C.J., Park, H.J. \& Lee, H. (2009) Shadow education systems, in: G. Sykes, B. Schneider \& D.N. Plank (Eds) Handbook of Education Policy Research (New York, Routledge for the American Educational Research Association), 901-919.

Lee, C.J., Lee, H. \& Jang, H.M. (2010) The history of policy responses to shadow education in South Korea: Implications for the next cycle of policy responses. Asia Pacific Education Review, 11 (1): 97-108.

Levin, L. (2009) Human rights: Questions and answers, $5^{\text {th }}$ edition (Paris, UNESCO). 
Lewin, K. (2011) Making rights realities: Researching educational access, transitions and equity (Consortium for Research on Educational Access, Transitions \& Equity [CREATE], Falmer, University of Sussex).

Machabeli, G., Bregvadze, T. \& Apkhazava, R. (2011) Examining private tutoring phenomenon in Georgia (Tbilisi, International Institute for Education Policy, Planning \& Management).

Makuwa, D. (2010) The SACMEQ III project: Mixed results in achievement. IIEP Newsletter XXVIII (3): 3.

Marhic, P. (2009) L'enseignement individuel: Une alternative à l'échec scolaire (Paris: L'Harmattan).

Marimuthu, T., J.S. Singh, K. Ahmad, H.K. Lim, H. Mukherjee, S. Oman, T. Chelliah, J.R. Sharma, N.M. Salleh, L. Yong, L.T. Leong, S. Sukarman, L.K. Thong, and W. Jamaluddin. (1991): Extraschool instruction, social equity and educational quality (Singapore, International Development Research Centre).

Mertus, J.A. (2009) The United Nations and human rights: A guide for a new era, $2^{\text {nd }}$ edition (London, Routledge).

Mori, I. \& Baker, D. (2010) The origin of universal shadow education: What the supplemental education phenomenon tells us about the postmodern institution of education. Asia Pacific Education Review, 11 (1), 36-48.

Morsink, J. (1999) The Universal Declaration of Human Rights: Origins, drafting and intent (Philadelphia, University of Pennsylvania Press).

Nath, S. (2011) Shadow education in Bangladesh. Presentation at a seminar organised by UNESCO in conjunction with the National Academy of Educational Management (NAEM), Dhaka, 11 August.

Noronha, C. and P. Srivastava (2012) The Right to Education Act in India: Focuses on early implementation issues and the private sector. Ottawa: Collaborative Research and Dissemination (CORD), University of Ottawa.

Oketch, M., Mutisya, M., Ngware, M. \& Ezeh, A.C. (2010) Why are there proportionately more poor pupils enrolled in non-state schools in urban Kenya in spite of FPE policy? International Journal of Educational Development, 30 (1), 23-32.

Pakistan, Government of (2010) Eighteenth amendment to the Constitution: Article 25A-Right to education (Islamabad: Government of Pakistan).

Peters, M., Carpenter, H., Edwards, G. \& Coleman, N. (2009) Private tuition: Survey of parents and carers. Research Brief DCSF-RBX-09-01. (London, Department for Children, Schools and Families).

Pratham (2012): Annual status of education report 2011 (Mumbai: Pratham).

Sen, A. (2009) Introduction: Primary schooling in West Bengal, in: K. Rana (Coordinator), The Pratichi education report II: Primary education in West Bengal - changes and challenges (New Delhi, Pratichi Trust).

Silova, I. (2010) Private tutoring in Eastern Europe and Central Asia: Policy choices and implications. Compare: A Journal of Comparative and International Education, 40 (3), 327-344.

Silova, I., Būdienè, V. \& Bray, M. (Eds) (2006) Education in a hidden marketplace: Monitoring of private tutoring (New York, Open Society Institute).

Smyth, E. (2009) Buying your way into college? Private tuition and the transition to higher education in Ireland. Oxford Review of Education, 35 (1), 1-22.

Sobhy, H. (2012) The de-facto privatization of secondary education in Egypt: A study of private tutoring in technical and general schools. Compare: A Journal of Comparative and International Education, 42 (1), 47-67. 
SAFED [South Asia Forum for Education Development] (2012) Annual status of education report 2011. (Islamabad, SAFED).

Tomasevski, K. (2003) Education denied: Costs and remedies (London, Zed Books).

UNDP (United Nations Development Programme) (2007) Educational transformations in Armenia: National human development report 2006 (Yerevan, UNDP).

UNESCO (2004): Education for all - The quality imperative: EFA global monitoring report 2005 (Paris, UNESCO).

UNESCO (2007) Education for all by 2015 - Will we make it? EFA global monitoring report 2008 (Paris, UNESCO).

UNESCO Institute for Statistics (2011) Financing education in sub-Saharan Africa: Challenges of expansion, equity and quality (Montreal, UNESCO Institute for Statistics).

United Nations (1948, reprinted 2007) Universal Declaration of Human Rights (New York, United Nations). http://www.un.org/events/humanrights/2007/hrphotos/declaration\%20_eng.pdf

United Nations (1959) Declaration of the rights of the child. General Assembly Resolution 1386 (XIV) (New York, United Nations). http://www.un.org/cyberschoolbus/humanrights/resources/child.asp

United Nations (1966) International covenant on economic, social and cultural rights. General Assembly resolution 2200A, XXI (New York, United Nations). http://www2.ohchr.org/english/law/cescr.htm

United Nations (1989) Convention on the rights of the child. General Assembly resolution 44/25 (New York, United Nations). http://www2.ohchr.org/english/law/crc.htm

United Nations (2000) Millennium development goals (New York, United Nations).

Ventura, A. \& Jang, S. (2010) Private tutoring through the internet: Globalization and offshoring, Asia Pacific Education Review, 11 (1), 59-68.

Walls, F. (2009) Mathematical subjects: Children talk about their mathematical lives (Dordrecht: Springer).

WCEFA [World Conference on Education for All] (1990a) World conference on education for all: Final report (New York, Inter-Agency Commission, WCEFA).

WCEFA [World Conference on Education for All] (1990b) World declaration on education for all (New York, Inter-Agency Commission, WCEFA).

WEF [World Education Forum] (2000) The Dakar framework for action - education for all: Meeting our collective commitments (Paris, UNESCO).

Windham, Douglas (1992) Education for all: The requirements - Roundtable themes III, World conference on education for all, Jomtien, Thailand (Paris, UNESCO).

Zajda, J. (2006) Introduction, in: J. Zajda (Ed), Decentralisation and privatisation in education: The role of the state (Dordrecht, Springer), 3-27.

Zeng, K. (1999) Dragon gate: Competitive examinations and their consequences (London, Cassell).

Zhang, Y. (2013) Does private tutoring improve students' national college entrance exam performance? A case study from Jinan, China'. Economics of Education Review, 32 (1), 1-28.

\section{Notes on the Authors}

Mark Bray is UNESCO Chair Professor in Comparative Education and Director of the Comparative Education Research Centre at the University of Hong Kong. He has taught at that University since 1986, prior to which he taught at the Universities of Edinburgh, Papua New Guinea and London and 
in secondary schools in Kenya and Nigeria. Between 2006 and 2010 he took leave from Hong Kong to work in Paris as Director of UNESCO's International Institute for Educational Planning (IIEP). He has written extensively in the field of comparative education, with particular focus on aspects of methodology and on the administration and financing of education. E-mail: mbray@hku.hk.

Ora Kwo is an Associate Professor in the Faculty of Education and a member of the Comparative Education Research Centre at the University of Hong Kong. Much of her work has focused on the work of teachers and on the methods and effectiveness of teacher education. This includes consideration of the implications of private supplementary tutoring for the work of teachers. She is a member of a Hong Kong research project which focuses on the nature and implications of private tutoring for the lives of secondary school students. She has also undertaken numerous international assignments for such bodies as UNESCO and the Asian Development Bank. E-mail: wykwo@hku.hk. 